\title{
Geological and Engineering Characteristics of Expansive Soils in Western Desert, Egypt
}

\author{
A Elshater ${ }^{1 *}$, MA Khashab ${ }^{1}$, MA El-Sherif ${ }^{2}$ and ES Abu Seif ${ }^{1}$ \\ ${ }^{1}$ Geology Department, Sohag University, Egypt \\ ${ }^{2}$ Civil Enginerring Department, Assiut University, Egypt
}

Submission: January 08, 2019; Published: February 04, 2019

*Corresponding author: Abdelhamid Elshater, Geology Department, Sohag University, Egypt

\begin{abstract}
Expansive shale has been found extensively in all over the world especially in arid and semi-arid regions. Egypt as a country from north Africa has alot areas having expansive soil. Superficial clay soil with the potential to shrink or swell with different degree of expansion covers large areas of many cities in New Valley Government such as Garb El-Mawhoob area. These problems include cracking, break-up of pavements, heaving, and damaging building foundations. Different laboratory tests were carried out on this soil including, natural water content, grain size distribution, Aterberge limits, unconfined compressive strength, swell potential and swelling pressure. These tests were supported by mineralogical investigations such as X-ray diffraction (XRD), scanning Electron Microscopy (SEM) and Differential thermal analysis (DTA). These soils were evaluated based on physico-chemical and geotechnical measurements. Its swelling potentiality (free swelling, swelling percent and swelling pressure) has a direct relationship with clay fraction content, plasticity index (PI) and cation exchange capacity (CEC). Furthermore, the clay fraction percent has a strong direct proportional relation to free swelling, plasticity index (PI) and cation exchange capacity (CEC). Also, the results of these tests showed that the clay in this area has considerable quantities of smectite resulting in the expansive character of these soils
\end{abstract}

Keywords: Garb El-Mawhoob area; X-ray diffraction; Smectite; Expansive soil

Abbrevations: SEM: scanning Electron Microscopy; PI: Plasticity Index; CEC: Cation Exchange Capacity; OMC; Organic Matter Content; TCEC: Total Cation Exchange Capacity

\section{Introduction}

Expansive soil is defined as partially saturated plastic soil that exhibits high volume change when its environmental conditions are altered from dry to wet. The degree of expansion depends on whether the soil mass contains active day minerals or not. The most common active clay minerals are smectite, sometimes chlorite and vermiculite, and a mixed-layer of smectite and other clay minerals Grim [1] and Sabtan [2]. These soils, which lie above the water table, undergo shrinkage on drying and swelling on wetting. Numerous reports of expansive soil problems and related damages have been documented in different countries [3-5]. A limited amount of these studies was concentrated on developing equations that could be used to predict the swelling potential of expansive clays from their index properties Chen [3]; Abduljauwad et al. [6]; AL-Homoud et al. [4]; Li et al. [7]; Al-Rawas [8]. These studies provide helpful information, which may be applicable to engineering practice.

Expansive soils occur extensively throughout the world and have been reported in numerous countries, including the
United States, India, South Africa, China, Romania, Jordan, Saudi Arabia and Egypt Chen [3]; Popescu [9]; Abduljauwad et al. [6], and Abu Seif \& El-Shater [5]. In Egypt, expansive soils are found in areas (Aswan, KomOmbo, Edfu, Luxur, Esna, Assiut, Sohag, Assuit Fayuim Suez, Esmaelia, Nasser City, Cairo-Suez Alsphaltic road, Sinai, etc.). This problem is considered as a severe engineering problem in New Valley of Egypt from both design and construction point of view. Buildings on expansive soils may heave, showing movement in a direction opposite to that which one normally expects as a consequence of building loads. Building foundations and semels may be subjected to swelling pressures causing excessive movements and consequently failure. Roads may also heave and differential movements may cause distortion and cracking of pavements. Canal linings, retaining walls and underground structures with expansive soil backfills may be subjected to considerably increased earth pressures with consequent displacement and damage.

In the Dakhla area the Dakhla Formation is a major geological sequence, where it comprises of three known members, from the 


\section{Civil Engineering Research Journal}

base to the top are MawhoobShale Member, Beris Oyster Mudstone Member and Kharga Shale Member. The three members are comprised predominately especially "Mawhoob Shale Member" of shale with occasionally claystones layers which is the bottom of the Dakhla Formation is weakly compacted, weakly cemented and contains significant amounts of swelling clay minerals. The arid climate and severe weathering environment imposed on Western Desert during its past geological history had a major influence on the wide occurrence of expansive soils in the region (Slater [10]). Gharb El-Mawhoob expansive clayey shales considered as one of the most problematic and least understood geological materials due to the wide variation in the engineering properties. Large areas of Gharb El-MawhoobVilage are covered with Mawhoob Shale Member of which having expansive nature. The swelling and shrinkage potential of these soils caused by mineralogical constitutes. Many buildings in Gharb El-Mawhoob area includes homes, schools, offices which have been damaged by the movements of the superficial expansive clayey soils, because the foundations design has not taken into consideration the expansive properties of these soils (Figure 1).
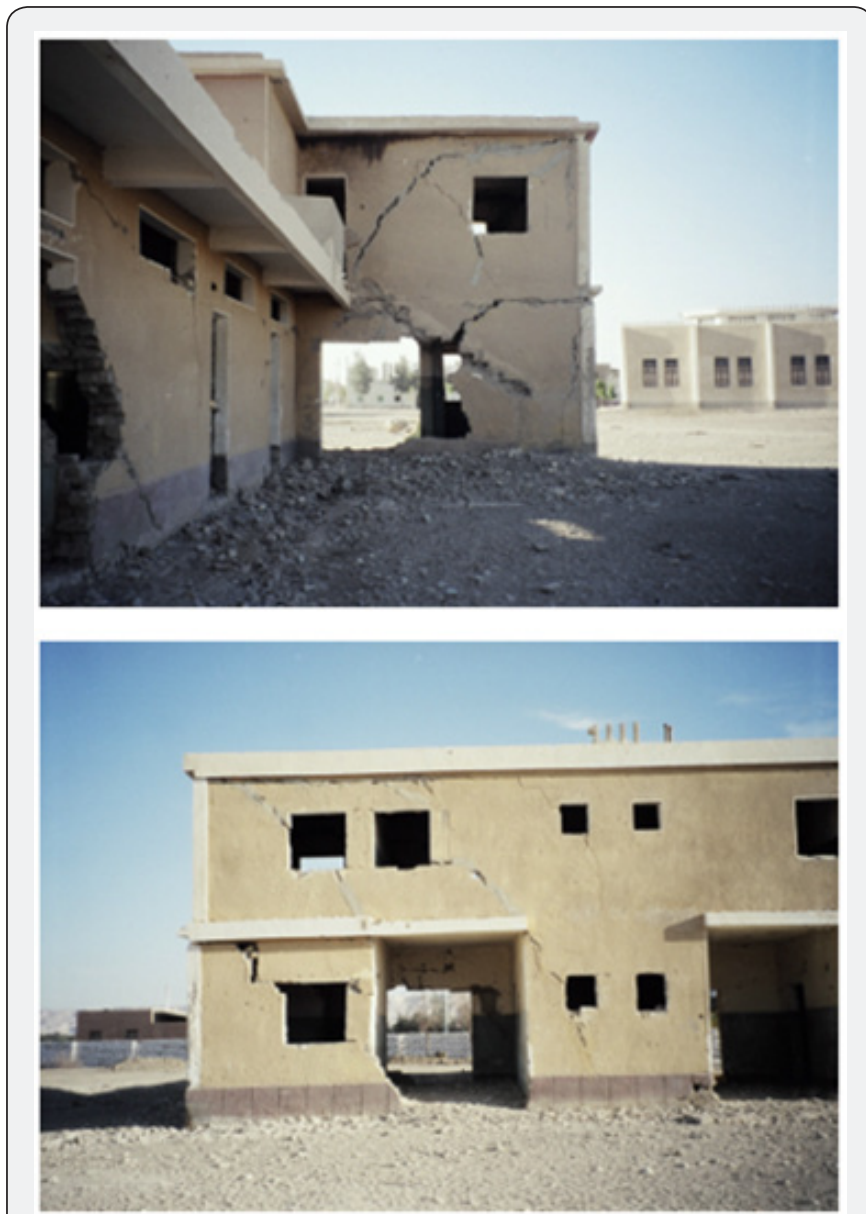

Figure 1: Buildings damaged by the movements of the superficial expansive clayey soils, Al-Mooaskar the Garab, ElMawhoob area, Dakhla Oasis, Western Desert.

Many investigations in different tropical regions of the world have made considerable research in an effort to recognize the engineering properties and to predict the swelling potential of the expansive soils in their regions. It seems that there is no investigation made on swelling soils in Egypt except the study carried by Youssef et al. [11] on the serious damage caused by swelling to the building of a hospital in Aswan. Superficial clay soil with the potential to shrink or swell with different degree of expansion covers large areas of many cities in New Valley Government such as Garb El-Mawhoob area. The thickness of these superficial deposits varies from few centimeters to more than 12 meters in the above-mentioned areas. These problems include cracking, break-up of pavements, heaving, and damaging building foundations.

This study is part of an effort to lead to improved geotechnical engineering practices by providing the engineering properties of these soils.

\section{Geological Setting of the Studied Area}

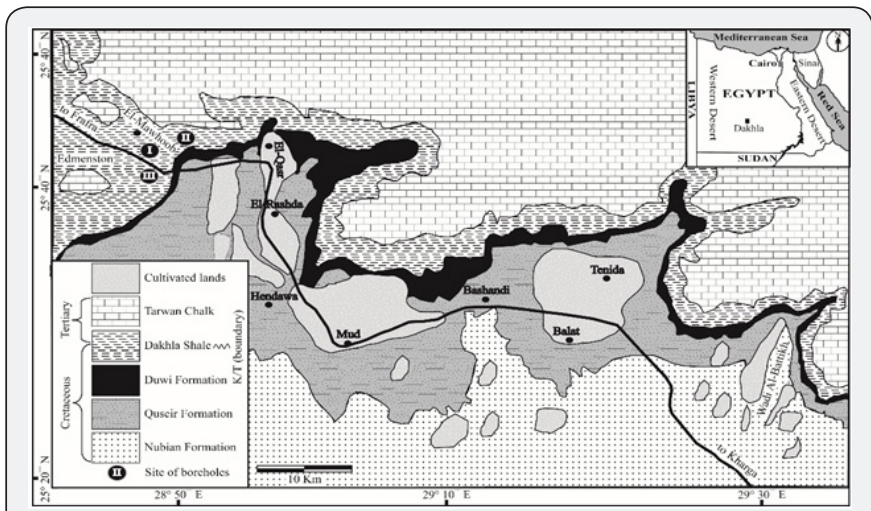

Figure 2: Geological map of the Garab El-Mawhoob area, Dakhla Oasis, Western Desert.

Gharb El Mawhoub area lies on NW of Dakhla Oasis, Western Desert of Egypt. This Oasis is about $490 \mathrm{Km}$ west of Assuit (City of the upper Egypt). It is bounded approximately by the latitude $25^{\circ} 35^{-} \mathrm{N}$, to $26^{\circ} 00^{-} \mathrm{N}$ and longitude $28^{\circ} 10^{-} \mathrm{E}$, to $28^{\circ}$ $54^{-} \mathrm{E}$ (Figure 2). The surface geology of the Dakhla Oasis and west Dakhla area have been the subject of a large number of investigations since the last century. Among the most significant are the works of Edmonstone [12], Zittle [13], Hermina et al. [14], Said [15], Abbass \&Habib [16], Issawi [17], Mansour [18], Omara et al. [19,20], El-Dawoody \& Zidan [21], Mansour et al. [22,23], Askalany [24], Barthel \& Herrmann-Degen [25], Bisewski (1982), El-Younsy [26] Luger \& Schrank [27], Hermina [28], El-Ezabi \& d El-Araby [29] and Tantawi, et al. [30]. The stratigraphic units recognized in the studied area are shown in its geological map (Figure 2). In this region, the upper strata are of Cretaceous age and consist of terrestrial sediments. This deposit, known as Gharb El-Mawhoob Shale Member, the basal member of the Dakhla Shale Formation, which consists mainly of gray shale, graded downward into grayish green shale, green shale, yellowish gray shale and greenish gray shale. These shales have been identified as expansive in nature Holtz \&Gibbs [3,3134]. 


\section{Civil Engineering Research Journal}

\section{Site and Soil Conditions}

Three boreholes (Sites I, II and III) were drilled in order to obtain undisturbed samples for laboratory testing (Figure 2 \& 3 ). The maximum depth of these boreholes is $10 \mathrm{~m}$.The soil profiles of these boreholes showed similar lithologies with variations in depth. Site selection was based on reported structural damages in the area due to expansive soil. The site of boreholes is underlain by a highly expansive soils which considered as a basal part of the Mawhoob Shale Member of Dakhla Formation (Early Maastrichtian age). The Mawhoob Shale Member in the studied boreholes consisting of the top layer (layer A, $1 \mathrm{~m}$ thick) of hard highly weathered gray shale (layer A), this layer was recorded only in borehole I. This layer is underlain by a $1 \mathrm{~m}$ thick layer (layer B) of dense grayish green shale. Layer B is underlain by a very dense green shale (layer $\mathrm{C}, 1 \mathrm{~m}$ thick). Beneath layer $\mathrm{C}$, the material changes to very hard yellowish gray shale (layer D, $1 \mathrm{~m}$ thick). or dense dark greenish gray shale (layer E). the thickness of this layer varies from $3 \mathrm{~m}$ in boreholes I and II to $7 \mathrm{~m}$ in boreholes III. Layer $\mathrm{E}$ is underlain by a very hard dense limestone (Layer F) which reocded only in boreholes I $(3 \mathrm{~m}$ thick) and II (4m thick).

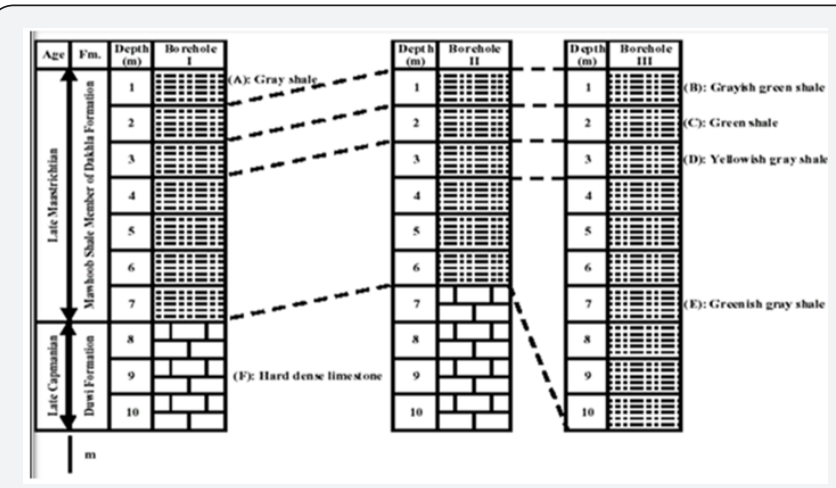

Figure 3: Typical subsurface profiles of the Gharb elmohob area.

\section{Material and Methods}

Representative samples of disturbed and undisturbed soils were obtained at different depths of the above-mentioned boreholes. The undisturbed samples were covered by wax and kept in a cool place until were used in engineering tests (which were done in soil mechanics laboratory in Assuit University). While the remoulded and undisturbed samples were collected from the same depths which were used in others geological tests. The physical and chemical characteristics of the collected samples were investigated to evaluate the main characters of Gharb El-Mawhoob expansive soil. Soil samples were subjected to the following test programs:

I. Determination of physico-chemical properties including organic matter content, carbonate content, $\mathrm{pH}$, cation exchange capacity (CEC) and exchangeable cations.

II. Determination of mineralogical composition by infrared spectral analysis (IR), differential thermal analysis (DTA) and X-ray diffraction (XRD).
III. Determination of geotechnical properties including grading, water content, Atterberg limits and density.

IV. Directmeasurements offree swelling, swelling potential, swelling pressure and volume change characteristics.

V. Determination of shearing strength characteristics and consolidation settlement of the studied samples.

VI. Studying microfabrics of the studied samples by using Scanning electron microscopy (SEM).

\section{Physico-Chemical Properties}

The physico-chemical property indices of studied soils such as total cation exchange capacity (TCEC), type of exchangeable cations, $\mathrm{pH}$, organic matter content (OMC) calcium carbonate content and moisture content are very important for understanding the engineering properties of expansive soil, which are often ignored by soil engineers. CEC and exchangeable cations were determined by atomic absorption spectrum. The physico-chemical indices of soil specimens are summarized in Table 1.

\section{pH values}

The $\mathrm{pH}$ is equivalent to the common logarithm of the reciprocal of the hydrogen ion concentration in solution. It is responsible for the occurrence of negative charges in soil constituents [35]. The $\mathrm{pH}$ dependent charges which occurs in soils is the result of the dissociation of the hydroxyl or carboxyl on the organic matter fraction of the soil or as result of the dissociation of the hydroxyl edges on the clay minerals. Another source of the $\mathrm{pH}$ dependent charges in strongly acid soils $\mathrm{(pH}$ below 5.5) are the adsorbed aluminum-hydroxyls polymers that are adsorbed on the negative exchange sites. As pH rises, these polymers precipitate out of solution and the exchange sites become free for other cations to be adsorbed iron oxides have a similar effect as the aluminum hydroxy polymers, but the effect can be seen at higher pHs. Swell potential is highly influenced by the exchange complex and to a lesser degree by the $\mathrm{pH}$ value especially for the K-clay.

The $\mathrm{pH}$ measurements were performed on 1:25 clay-water suspensions using a glass electrode $\mathrm{pH}$-meter. Test results shown in Table 1 indicate the $\mathrm{pH}$ value of most Gharb el-Mawhooob soils are above 7 which indicate the alkaline environment of the Gharb el-Mawhooob area.

\section{Exchangeable cations}

This is a measure of the type and amount of cations adsorbed into the clay minerals. The amount of exchangeable cations, sodium, calcium, magnesium and potassium were determined using the atomic absorption (flame and lamp photometry) techniques. Table 1 summarizes the exchangeable soil cations of the Gharb el-Mawhooob soil samples. Test results indicate that Gharb el-Mawhooob soils have a greater concentration of calcium and sodium cations than of magnesium and potassium. 


\section{Civil Engineering Research Journal}

\section{Cation exchange capacity}

Cation exchange capacity (CEC) has a major significance in determining the properties of clay minerals, particularly the facility by which they adsorb water. CEC is defined by the quantity of exchangeable cations required to balance the charge deficiency of clay and is usually expressed in the mill equivalent of the atomic weight of solvent per 100 grams of soil. The CEC has been determined according to Allen's procedure [36]. The values vary from 49.6 to $70.7 \mathrm{meq} / \mathrm{I} 00 \mathrm{~g}$ as shown in Table 1 , which indicate the presence of expansive clay minerals (smectites).

Table 1: Summary of the physico-chemical test data for selected soil samples from the studied area.

\begin{tabular}{|c|c|c|c|c|c|c|c|c|c|c|c|c|c|}
\hline $\begin{array}{c}\text { Bore- } \\
\text { hole } \\
\text { No. }\end{array}$ & Sample & Depth & $\begin{array}{c}\text { pH } \\
\text { Values }\end{array}$ & $\begin{array}{c}\text { Organic } \\
\text { Matter } \\
\text { Content } \\
\quad \%\end{array}$ & $\begin{array}{c}\mathrm{CaCO}_{3} \\
\text { con- } \\
\text { tent\% }\end{array}$ & $\begin{array}{c}\text { Bulk } \\
\text { Density } \\
(\mathbf{g m} / \\
\mathbf{c m}^{3} \text { ) }\end{array}$ & $\begin{array}{c}\text { DryDen- } \\
\text { sity }(\mathrm{gm} / \\
\left.\mathrm{cm}^{3}\right)\end{array}$ & $\begin{array}{l}\text { Mois- } \\
\text { ture } \\
\text { Content }\end{array}$ & CEC & $\mathrm{Ca}++$ & Mg++ & $\mathrm{K}+$ & $\mathrm{Na}+$ \\
\hline \multirow{7}{*}{ Site I } & 1 & 1 & 7.96 & 3.56 & 18 & 1.74 & 1.4 & 10.3 & 56.5 & 48.8 & 4.1 & 1.7 & 0.9 \\
\hline & 2 & 2 & 7.93 & 4.22 & 19 & 1.83 & 1.5 & 22.32 & 67.6 & 58.1 & 4.5 & 1.7 & 1.3 \\
\hline & & 3 & 7.81 & 3.83 & 18 & 1.92 & 1.6 & 29.26 & 57.4 & 46.6 & 4.9 & 1.8 & 1.1 \\
\hline & 4 & 4 & 7.95 & 3.99 & 21 & 1.92 & 1.6 & 27.86 & 49.6 & 39.1 & 4.12 & 1.5 & 0.9 \\
\hline & 5 & 5 & 7.83 & 4.71 & 18 & 1.95 & 1.6 & 25.34 & 58.7 & 46 & 4.7 & 1.9 & 1.12 \\
\hline & 6 & 6 & 7.97 & 7.57 & 19 & 1.96 & 1.6 & 24.85 & 60 & 46.2 & 4.8 & 1.8 & 1.2 \\
\hline & 7 & 7 & 7.86 & 2.05 & 21 & 1.88 & 1.5 & 22.37 & 61.5 & 45.8 & 5.5 & 1.8 & 1.4 \\
\hline \multirow{6}{*}{ Site II } & 1 & 1 & 7.91 & 3.64 & 18 & 1.87 & 1.5 & 15.8 & 51.7 & 42 & 6.2 & 1.6 & 0.9 \\
\hline & 2 & 2 & 7.85 & 2.28 & 19 & 1.89 & 1.5 & 26.27 & 58.9 & 50.1 & 4.1 & 1.8 & 0.9 \\
\hline & 3 & 3 & 7.79 & 2.85 & 19 & 1.89 & 1.5 & 27.35 & 68.3 & 57.8 & 4.5 & 1.7 & 1.3 \\
\hline & 4 & 4 & 7.74 & 5.54 & 21 & 1.9 & 1.6 & 28.51 & 58.9 & 47 & 4.9 & 1.9 & 1.1 \\
\hline & 5 & 5 & 7.73 & 4.07 & 19 & 1.94 & 1.6 & 24.89 & 52.6 & 41 & 4.2 & 1.5 & 0.9 \\
\hline & 6 & 6 & 7.81 & 4.11 & 19 & 1.93 & 1.6 & 25.7 & 67.9 & 54 & 4.7 & 1.9 & 1.3 \\
\hline \multirow{10}{*}{ Site III } & 1 & 1 & 7.13 & 1.51 & 18 & 1.8 & 1.5 & 14.32 & 62.1 & 53 & 5.1 & 1.7 & 1.2 \\
\hline & 2 & 2 & 6.89 & 2.73 & 17 & 1.9 & 1.6 & 23.59 & 66.1 & 55.5 & 5.4 & 1.8 & 1.4 \\
\hline & 3 & 3 & 7.11 & 3.33 & 17 & 1.92 & 1.6 & 26.87 & 55 & 43.2 & 6.2 & 1.5 & 1.1 \\
\hline & 4 & 4 & 7.19 & 3 & 18 & 1.95 & 1.6 & 27 & 59.7 & 48.8 & 4.3 & 1.7 & 0.9 \\
\hline & 5 & 5 & 7.38 & 3.21 & 17 & 1.9 & 1.6 & 28 & 70.7 & 58.1 & 4.5 & 1.8 & 1.3 \\
\hline & 6 & 6 & 7.47 & 3.23 & 16 & 1.92 & 1.6 & 28.5 & 60.9 & 47 & 4.9 & 1.9 & 1.1 \\
\hline & 7 & 7 & 7.36 & 1.2 & 17 & 1.89 & 1.5 & 27.81 & 55.1 & 41.2 & 4.3 & 1.4 & 1.2 \\
\hline & 8 & 8 & 7.25 & 2.79 & 18 & 1.97 & 1.6 & 25.66 & 61.8 & 46 & 4.7 & 1.9 & 1.22 \\
\hline & 9 & 9 & 7.36 & 4.61 & 15 & 1.99 & 1.6 & 23.85 & 63.8 & 47 & 4.9 & 1.7 & 1.2 \\
\hline & 10 & 10 & 7.4 & 10.7 & 13 & 2.1 & 1.8 & 22.29 & 66.8 & 48 & 5.6 & 1.8 & 1.4 \\
\hline
\end{tabular}

\section{Organic matter content (OMC)}

Organic matter plays an important role in the formation of soil materials. The increase of organic content increases the soil plasticity. Other studies found that the maximum dry density of compaction decreased with increasing organic content whereas the optimum moisture content increased with increasing organic content. With increasing organic content, the plastic limit and the liquid limit of soil increase. The organic matter content (OMC) values of the studied samples varying from 1.2 to 10.65 (Table 1).

\section{Calcium carbonate content}

Following Jackson [37] the calcium carbonate content was determined. The calcium carbonate content (CCC) values of the studied samples varying from 13.33 to 21.27 (Table1). There is a general tendency for both liquid limit and plasticity index to decrease with the increase of calcium carbonate content. From relation between water content and calcium carbonate content it is noticed that the water content absorbed from humid atmosphere decreases with the increase of calcium carbonate content. Such result is expected because clay mineral content decreases and consequently amount of adhered water decreases, with the increase of calcium carbonate content.

\section{Moisture content}

Representative samples were dried in an oven at $105{ }^{\circ} \mathrm{C}$ For about 18hours. After samples had been dried to a constant weight moisture content percent was calculated. The moisture water content of the present studied samples varying from 10.3 to 29 (Table 1). Kassif et al. [38] mentioned that all the structures which rest on, or founded within, particularly saturated clays are prone to damage caused by movement of the soil with 
changing moisture condition. Uppal \& Palit [39] mentioned that swell pressure depends upon the range through which moisture changes. They stated that for accurate assessment of swell pressure, it is necessary to know the extreme variation in the moisture content of the expansive subgrade soil. Brackley [40] concluded that the swell pressure is a function of final moisture content and void ratio. Moafi [41] found that the initial water content had a small effect on the swelling pressure until it reached the shrinkage limit. Higher than the shrinkage limit, the rate of decrease in swelling pressure by increasing water content become quicker.

\section{Mineralogical Identification}

The engineering properties of any type of soil are controlled by its mineralogical constituents, especially those comprising the clay fraction. Twenty-three representative clayey soil samples were chosen for mineralogical investigation from the previously mentioned sites These samples were mechanically wet sieved to obtain the less than $630 \mathrm{~m}$ fraction, then (10$20 \mathrm{gm})$ was treated with $1 \mathrm{M}$ Na OAc buffer solution $(\mathrm{pH}=5)$ to remove calcium carbonates and with $\mathrm{H} 2 \mathrm{O} 2$ to get rid the organic matter. Finally, the residue was treated with sodium dithonite to remove iron oxides. The suspension was transformed into standard precipitation cylinders. The clay fraction (?20 2 ) was separated using standard pipette sedimentation technique.

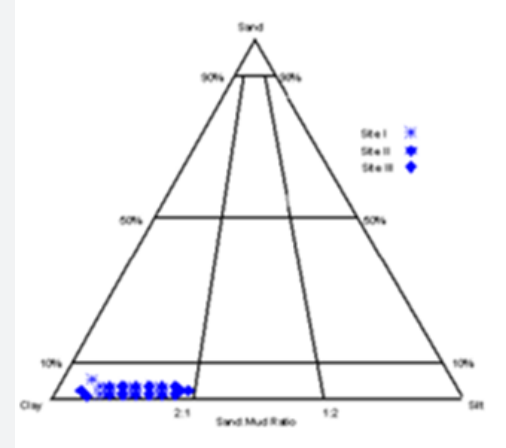

Figure 4: Triangular Diagram of the studied samples (after Folk, 1974).

The clay fraction (? 2? $\mathrm{m}$ ) of each sample was divided into three portions: the first portion for IR analysis, the second portion for DTA analysis, and lastly the third portion for XRD analysis. For X-ray diffraction analysis-oriented particles were obtained by careful sedimentation into clean slides. Three slides per sample were prepared: one slide was X-rayed without further post treatment "untreated". The second was heated to about $550 \mathrm{C}$ ? for two hours "heated". The third was placed in an ethylene atmosphere at 60 C? over-night "glycolated". X-ray diffraction (XRD) was performed using Philips Pw 1710 diffactometer. A potential of $40 \mathrm{Kv}$ and a current of $55 \mathrm{~mA}$ were applied on $\mathrm{Cu}$ target tube. A nickel filter was used to prevent radiations other than $\mathrm{K}$ ?. The studied samples were scanned

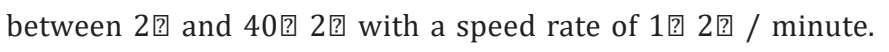

The obtained X-ray charts were used for the clay mineral identification and quantification. The identification of the clay minerals is based on the basal reflections (001), according to the X-ray powder diffraction results of Weaver [42-43], Carrol [44], Chen [45] and the ASTM cards [46]. Four types of clay minerals were identified throughout the studied sequence, namely kaolinite, smectiteillite, and. smectite-illite mixed-layer (Table 2, and Figure 4).

Table 2: Summary of measured Atterberg limits and water content of the studied soils.

\begin{tabular}{|c|c|c|c|c|c|c|}
\hline $\begin{array}{c}\text { Bore- } \\
\text { hole } \\
\text { No. }\end{array}$ & Sample & Depth & $\begin{array}{c}\text { Liquid } \\
\text { limit } \\
\text { (LL) } \\
(\%)\end{array}$ & $\begin{array}{c}\text { Plastic } \\
\text { Limit } \\
\text { (PL) } \\
(\%)\end{array}$ & $\begin{array}{c}\text { Plastic } \\
\text { Index } \\
\text { (PI) }\end{array}$ & $\begin{array}{c}\text { Final } \\
\text { Water } \\
\text { Content } \\
\text { (\%) }\end{array}$ \\
\hline \multirow{7}{*}{ Site I } & 1 & 1 & 84 & 35 & 49 & \\
\hline & 2 & 2 & 83 & 34 & 49 & \\
\hline & 3 & 3 & 82 & 36 & 46 & 17.3 \\
\hline & 4 & 4 & 81 & 35 & 46 & \\
\hline & 5 & 5 & 80 & 34 & 46 & 17.6 \\
\hline & 6 & 6 & 79 & 35 & 44 & \\
\hline & 7 & 7 & 81 & 34 & 47 & 17.3 \\
\hline \multirow{6}{*}{ Site II } & 1 & 1 & 84 & 35 & 49 & \\
\hline & 2 & 2 & 83 & 35 & 48 & 17.5 \\
\hline & 3 & 3 & 84 & 36 & 48 & \\
\hline & 4 & 4 & 83 & 37 & 46 & 17.2 \\
\hline & 5 & 5 & 81 & 34 & 47 & \\
\hline & 6 & 6 & 84 & 35 & 49 & 17.4 \\
\hline \multirow{10}{*}{ Site III } & 1 & 1 & 82 & 33 & 49 & \\
\hline & 2 & 2 & 81 & 34 & 47 & \\
\hline & 3 & 3 & 84 & 33 & 51 & 18.1 \\
\hline & 4 & 4 & 84 & 36 & 48 & \\
\hline & 5 & 5 & 82 & 36 & 46 & 17.6 \\
\hline & 6 & 6 & 79 & 35 & 44 & 17.9 \\
\hline & 7 & 7 & 79 & 36 & 43 & \\
\hline & 8 & 8 & 83 & 36 & 47 & \\
\hline & 9 & 9 & 84 & 37 & 47 & \\
\hline & 10 & 10 & 85 & 35 & 50 & 17.4 \\
\hline
\end{tabular}

Table 2 summarizes the calculation of the relative amounts of clay minerals in each tested soil sample from the studied area. The calculation was done by considering the integrated intensity of the $17 \AA$ glycolated peak area as being equivalent to the relative amount of smectite with minor chlorite. The area of $10 \AA$ (glycolated trace) multiplied by four is equivalent to the relative amount of illite. The $7 \AA$ peak area was multiplied by two forthe relative amount of kaolinite with some chlorite (Carrol, 1974).

The presence of smectite indicates that these soils originate from weathered parent igneous rocks. The presence of considerable quantities of smectite is a good indicator of the expansive potential of these soils. 


\section{Civil Engineering Research Journal}

Differential thermal analysis (DTA) of clay fractions of the studied soils show a large endothermic peak at $120{ }^{\circ} \mathrm{C}$ which represents the dehydration reaction of clay particles (Figure 5). Variation in size and intensity of the observed peak is attributed to the quantity of water absorbed on the surfaces of layer silicates which has a direct relation to the amount of expansible layer silicates in each fraction and to the total external area exposed by the minerals. The second small endothermic peak at about $575^{\circ} \mathrm{C}$ is probably due to the kaolinite dihydroxylation. The third endothermic peak at about $728{ }^{\circ} \mathrm{C}$ is due to dehydroxylation of smectite-chlorite minerals. The exothermic peak at about $880{ }^{\circ} \mathrm{C}$ is due to the change of phases in clay minerals Mackenzie [47]; Brown, 1988.
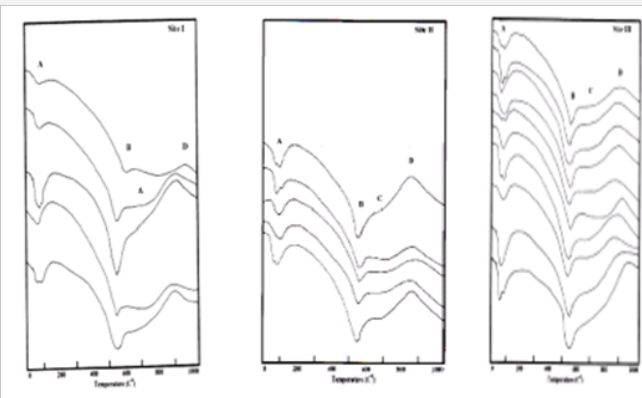

Figure 5: DTA curves of clay fractions of the studied soils (Sitesl, II and III).

Using IR analysis, the structural composition of the clay minerals can be recognized. The diagnostic interlayer Al-O group appears as an intense absorption band (A) in the spectrum range $3695-3445 \mathrm{~cm}-1$. From the IR analysis the main groups of clay mineral consisting the kaolinite, smectite, illite, and mixed layer (smectite-illite) were identified without any detailed information about their crystallinity. Finally, results of mineral composition of the clay fraction of the studied sediments, deduced from infrared spectral analysis (IR) and the diffraction thermal analysis (DTA) are in a good agreement with those revealed by and X-ray diffraction analysis (XRD). In addition, each of these analyses was unique in offering information about the characteristics related to every clay mineral species.

\section{Geotechnical Properties}

The particle size distribution of the tested soil samples was determined by using both sieves washing analysis and hydrometer analysis. Based on the ternary diagram of it is clear from (Figure 5) that the classes fractions of the studied samples were lied in field of clay indicating a narrow range. Atterberg limits, plasticity index, and water content are shown in Table 2 [48]. Both the Unified Soil Classification System (USCS) and the American Association of State Highway and Transportation Officials (AASHTO) system were used in classification of the tested soils. Accordingly, the studied soil belongs to the $\mathrm{CH}$ group of the high plastic inorganic clay in the USCS system and to the A-7-6 group, which is composed of silt and fine clay, in the AASHTO system. Gromko [49], has classified expansive soils based on their index properties as shown in Table 3. According to this classification, the studied soils can be characterized as highly expansive since the values of Atterberg limits for a large number of samples fall within the range of very high expansion Figure 6.
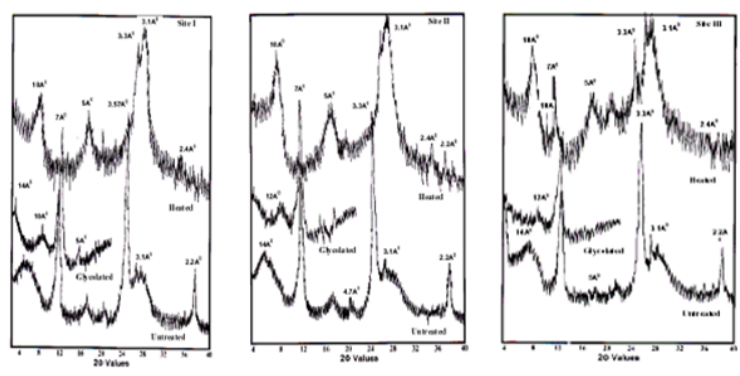

Figure 6: X-ray diffraction patterns of less than 2 microns size fractions of the studied clayey soils at sites I,II and II.

Table 3: Relative percentage of identified clay mineral species in the studied samples.

\begin{tabular}{|c|c|c|c|c|c|c|}
\hline $\begin{array}{l}\text { Local- } \\
\text { ity }\end{array}$ & $\begin{array}{c}\text { Sam- } \\
\text { ple }\end{array}$ & Depth & $\begin{array}{l}\text { Kaolin- } \\
\text { ite }\end{array}$ & $\begin{array}{l}\text { Smec- } \\
\text { tite }\end{array}$ & Illite & $\begin{array}{c}\text { Mixed-lay- } \\
\text { er (S /I) }\end{array}$ \\
\hline \multirow{7}{*}{ Site I } & 1 & 1 & 32.4 & 56.8 & 6.8 & 4 \\
\hline & 2 & 2 & 31.5 & 59 & 6.6 & 2.9 \\
\hline & 3 & 3 & 39 & 51.2 & 6.1 & 3.7 \\
\hline & 4 & 4 & 25 & 62.5 & 8.3 & 4.21 \\
\hline & 5 & 5 & 31.7 & 59.7 & 6.3 & 2.2 \\
\hline & 6 & 6 & 24.5 & 65 & 7.3 & 3.2 \\
\hline & 7 & 7 & 33.1 & 56 & 6.6 & 4 \\
\hline \multirow{6}{*}{ Site II } & 1 & 1 & 27.4 & 49.3 & 13 & 10.3 \\
\hline & 2 & 2 & 33.9 & 48.3 & 8.1 & 9.7 \\
\hline & 3 & 3 & 19.8 & 70.2 & 6 & 4 \\
\hline & 4 & 4 & 22.6 & 59.2 & 14 & 4.3 \\
\hline & 5 & 5 & 24.1 & 65.6 & 5.6 & 4.7 \\
\hline & 6 & 6 & 26 & 64 & 5.2 & 4.8 \\
\hline \multirow{10}{*}{ Site III } & 1 & 1 & 20.8 & 61.5 & 7.8 & 9.9 \\
\hline & 2 & 2 & 29.8 & 48.9 & 5.3 & 16.6 \\
\hline & 3 & 3 & 21.5 & 59.5 & 7.1 & 11.9 \\
\hline & 4 & 4 & 21.9 & 63 & 6.8 & 8.3 \\
\hline & 5 & 5 & 22.9 & 66.9 & 6.4 & 3.8 \\
\hline & 6 & 6 & 44.4 & 42.4 & 6.1 & 7.1 \\
\hline & 7 & 7 & 28.6 & 62.8 & 5.7 & 2.9 \\
\hline & 8 & 8 & 9.7 & 78.7 & 7.5 & 4.1 \\
\hline & 9 & 9 & 24.9 & 59.6 & 5.5 & 10 \\
\hline & 10 & 10 & 24.6 & 67 & 5.6 & 2.8 \\
\hline
\end{tabular}

Vijayvergiya \& Ghazzaly [32] have proposed a classification on the basis of the plasticity limit and the plasticity index. The Casagrande plasticity chart is divided into two zones by the 


\section{Civil Engineering Research Journal}

line-A, with expansive soils above the line and non-expansive soils below it. The studied soil samples were lied above line-A indicating that these samples are expansive ones (Figure 7). Mouroux et al. [50] introduce an additional factor- activity. This is defined as the ratio between the plasticity index and the percentage clayey fraction. With the chart porposed by these authors it is possible to assess the swelling potential on the basis of the activity, the clayey fraction and the plasticity chart index. The studied soil samples were lied in the field of high and very high expansion characteristics (Figure 8). Referring to the results shown in Tables l, 2, 4 and figures (9-13) it can be concluded that there is positive correlation between smectite percentages and values of both of CEC, Atterberg limits and total swelling [51].

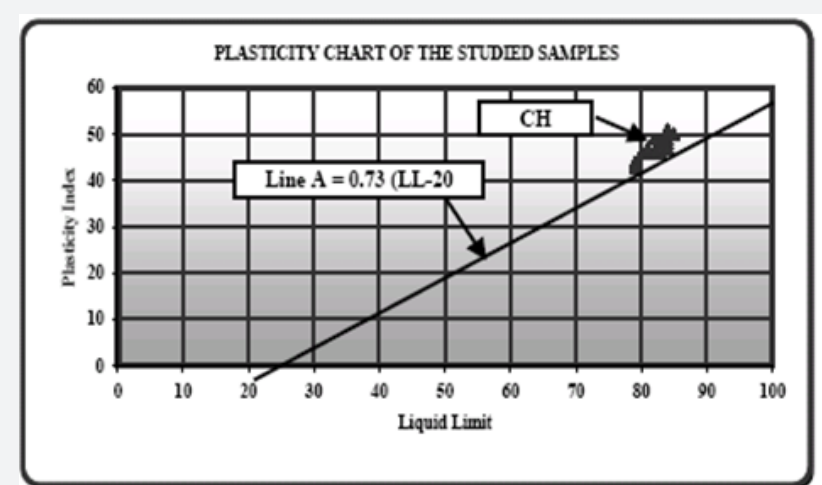

Figure 7: Plasticity chart of the studied samples. 91a.

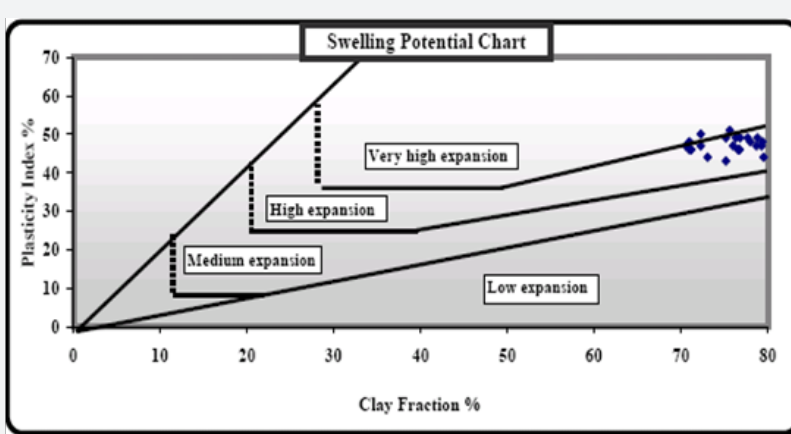

Figure 8: Swelling potential chart of the studied samples. 91b.

Table 4: Test results of Free Swelling, Expansiveness, total swelling percent $\%$, and total swelling pressure of the studied soils.

\begin{tabular}{|c|c|c|c|c|c|c|}
\hline $\begin{array}{c}\text { Bore- } \\
\text { hole } \\
\text { No. }\end{array}$ & Sample & Depth & $\begin{array}{c}\text { Free } \\
\text { Swell- } \\
\text { ing }\end{array}$ & $\begin{array}{c}\text { Expan- } \\
\text { sive- } \\
\text { ness }\end{array}$ & $\begin{array}{c}\text { Total } \\
\text { Swell- } \\
\text { ing } \\
\text { Per- } \\
\text { cent \% }\end{array}$ & $\begin{array}{c}\text { Total } \\
\text { Swell- } \\
\text { ing } \\
\text { Pres- } \\
\text { sure } \\
(\mathrm{kg} / \\
\left.\mathrm{cm}^{2}\right)\end{array}$ \\
\hline \multirow{7}{*}{ Site I } & 1 & 1 & 155 & Critical & & \\
\hline & 2 & 2 & 155 & “" & & \\
\hline & 3 & 3 & 160 & “" & 35 & 11.6 \\
\hline & 4 & 4 & 150 & “" & & \\
\hline & 5 & 5 & 150 & “” & 32 & 10.6 \\
\hline & 6 & 6 & 160 & “” & & \\
\hline & 7 & 7 & 155 & “"” & 28 & 11.1 \\
\hline
\end{tabular}

\begin{tabular}{|c|c|c|c|c|c|c|}
\hline \multirow{6}{*}{ Site II } & 1 & 1 & 158 & "u' & & \\
\hline & 2 & 2 & 160 & (") & 35 & 10.8 \\
\hline & 3 & 3 & 154 & “" & & \\
\hline & 4 & 4 & 158 & “" & 33 & 9.8 \\
\hline & 5 & 5 & 156 & "' & & \\
\hline & 6 & 6 & 160 & “'” & 31 & 10.2 \\
\hline \multirow{10}{*}{ Site III } & 1 & 1 & 150 & “" & & \\
\hline & 2 & 2 & 154 & “" & & \\
\hline & 3 & 3 & 154 & “"' & 37 & 9.1 \\
\hline & 4 & 4 & 160 & "'” & & \\
\hline & 5 & 5 & 158 & “"' & 33 & 10.9 \\
\hline & 6 & 6 & 157 & “" & 31 & 11.7 \\
\hline & 7 & 7 & 165 & “" & & \\
\hline & 8 & 8 & 150 & “"' & & \\
\hline & 9 & 9 & 150 & '"' & & \\
\hline & 10 & 10 & 150 & “" & 28 & 10.4 \\
\hline
\end{tabular}

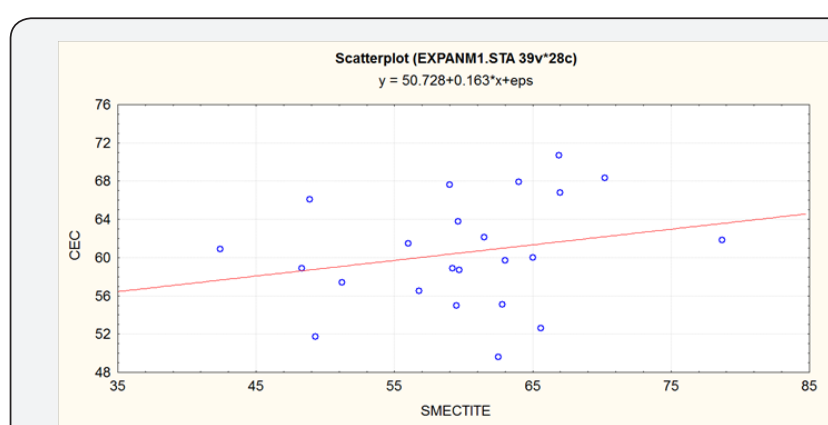

Figure 9: Relationship between CEC and smectie contents of the studied sediments.

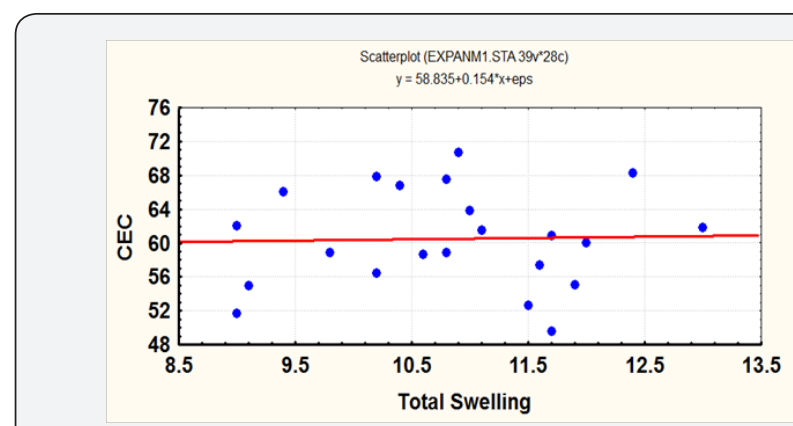

Figure 10: Relationship between CEC and total swelling pressure of the studied sediments.

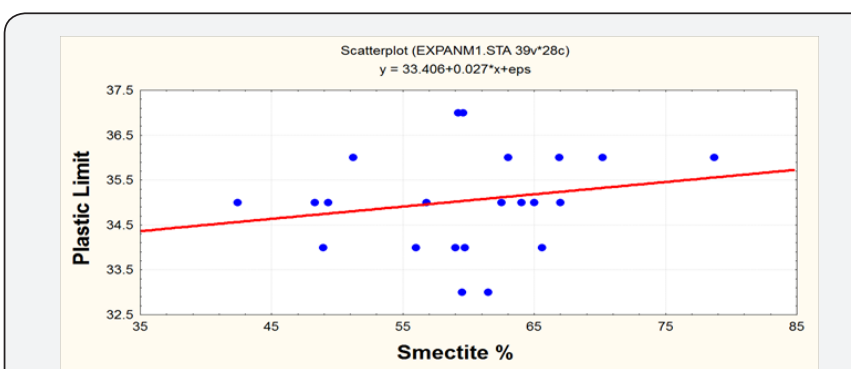

Figure 11: Relationship between smectie contents and plastic limits of the studied sediments. 


\section{Civil Engineering Research Journal}

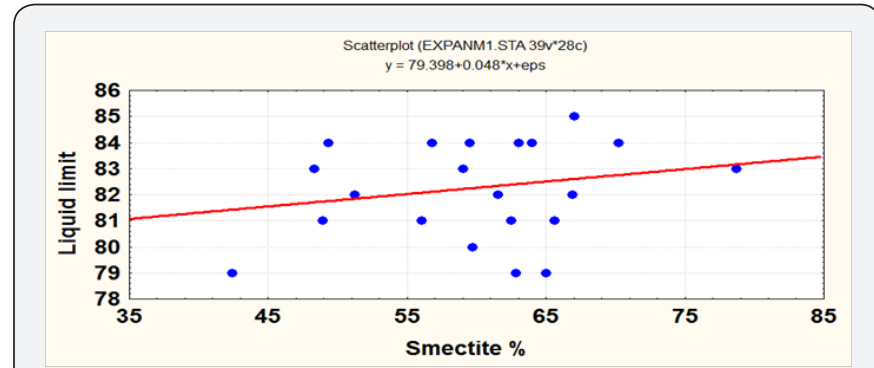

Figure 12: Relationship between smectie contents and liqid limits of the studied sediments.

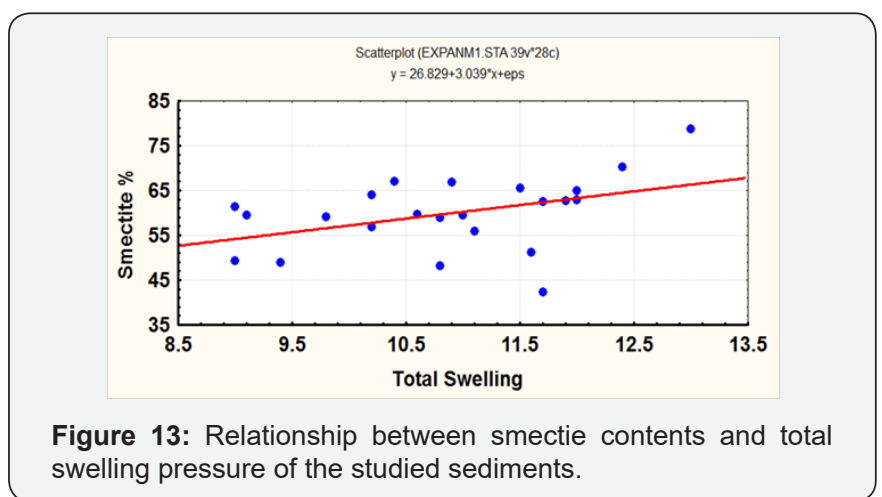

\section{Swelling Characteristics}

The swelling potential of an expansive soil can be measured directly by: axial free swelling, percentage of swell and swelling pressure tests. These swelling parameters were measured in the laboratory by using the standard one-dimensional odometer apparatus. In this study an additional procedure, based on volume charge measurements under a specified confining pressure, was used to estimate the swelling potential.

\section{Axial free swelling}

The free swell test was carried out typically as described by Holtz \& Gibbs [31]. The free swell values of the studied samples ranged between 150 and 165 (Table 1).

\section{Swelling pressure test}

Swell tests were performed to quantify the amount of vertical swell and swelling pressure. Swelling pressure is equivalent to the external applied load required to return a pre-swelled specimen to its initial volume [52]. The swelling pressure of Gharb El-Mawhoob soil varies from $9.1 \mathrm{~kg} / \mathrm{cm} 2$ to $11.7 \mathrm{~kg} / \mathrm{cm} 2$ (Table 2).

\section{Swell Percent}

The swelling percentage is defined as the percentage ratio between the increase in specimen height $(\Delta \mathrm{H})$ under a standard stress to the initial height of specimen (Ho). This testing led to a value of swelling percentages ranging from $28 \%$ to $37 \%$ of the initial volume of the samples (Table 2). Referring to Table 5 , it is clear that those samples which have a high percentage of smectite and high values of CEC as well as Atterberg limits show high swelling potential, axial free swelling and swelling pressure, such as sample number 5 , borehole 2, location1. Comparison of the swelling potential and swelling pressure of AI-Madinah expansive soils with other expansive soil formations found in the Kingdom indicates that the A1-Madinah soils can be categorized as highly expansive.

Table 5: Classification of swelling soils based on index tests.

\begin{tabular}{|c|c|c|c|c|}
\hline $\begin{array}{c}\text { Perentage } \\
\text { Passing } \\
\mathbf{2 0 0}\end{array}$ & $\begin{array}{c}\text { Liquid } \\
\text { Limit \% }\end{array}$ & $\begin{array}{c}\text { Plasiticity } \\
\text { Index \% }\end{array}$ & $\begin{array}{c}\text { Shrinkage } \\
\text { Limit \% }\end{array}$ & $\begin{array}{c}\text { Degree of } \\
\text { Expan- } \\
\text { sion\% }\end{array}$ \\
\hline$<30$ & $<30$ & $<18$ & $>15$ & Low \\
\hline $30-60$ & $30-40$ & $15-28$ & $10-16$ & Medium \\
\hline $60-95$ & $40-60$ & $25-41$ & $7-12$ & High \\
\hline$>95$ & $>60$ & $>35$ & $<11$ & Very high \\
\hline
\end{tabular}

\section{Microstructure}

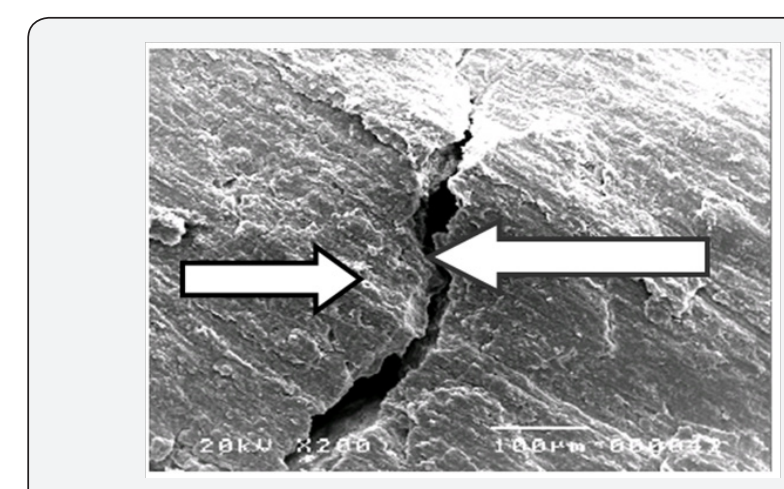

Figure 14: SEM photomicrograph illustrating de-watering cracks oblique to bedding plane (sample 1-3).

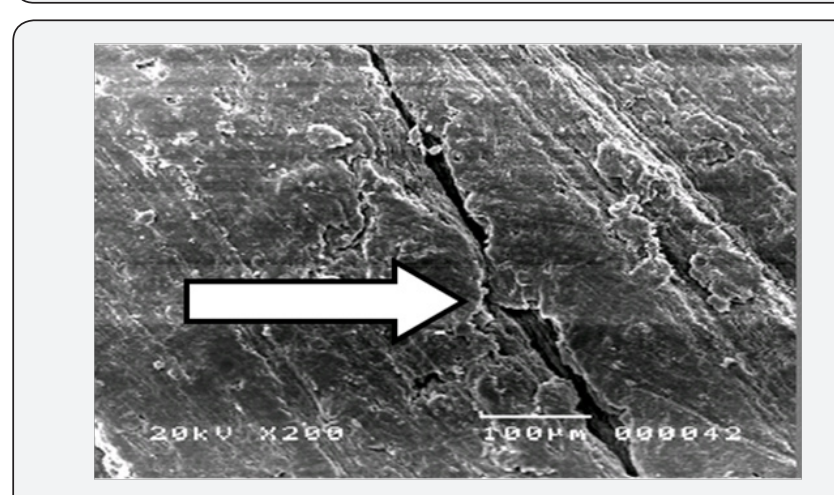

Figure 15: SEM photomicrograph illustrating de-watering crack parallel to bedding plane (sample I-7).

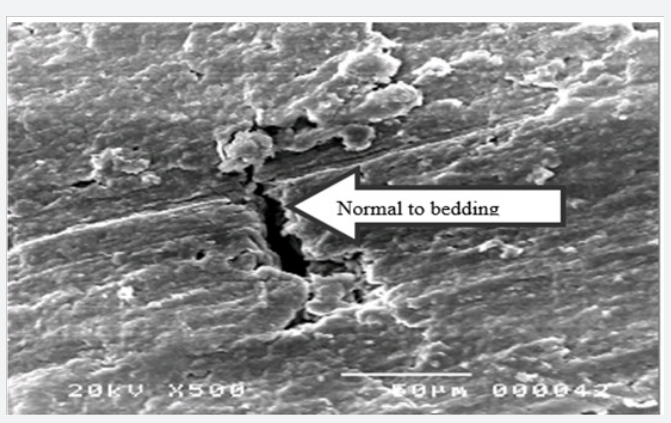

Figure 16: SEM photomicrograph illustrating de-watering crack normal to bedding plane (sample II-3). 


\section{Civil Engineering Research Journal}

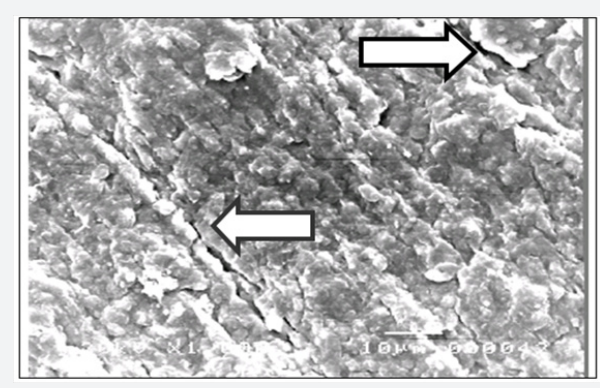

Figure 17: SEM photomicrograph illustrating de-watering cracks parallel to bedding plane (sample II-5).

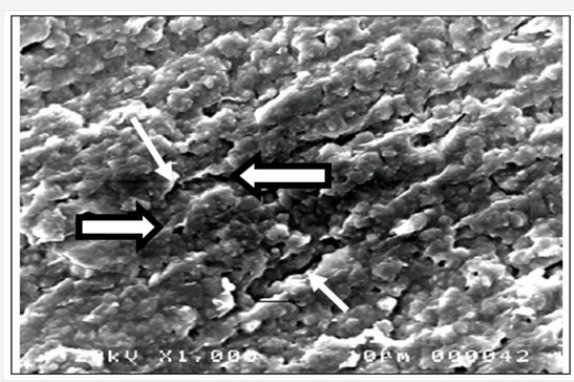

Figure 18: SEM photomicrograph illustrating de-watering cracks parallel, oblique and perpendicular to bedding planes (sample III-2).
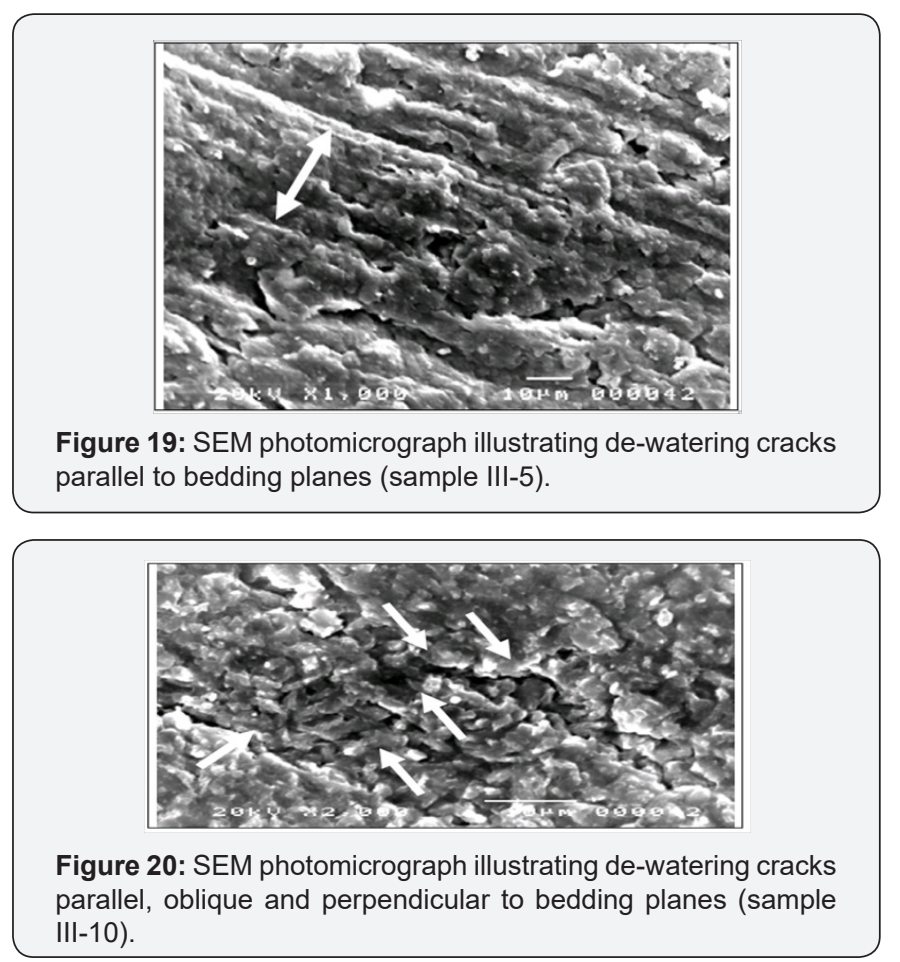

As is similar to material composition, the microstructure is also a basic factor that influences soil engineering properties (Push, 1979; Mitchell [53]). Knowledge of the clay mineralogy and fabric can help in developing a better understanding of soil behaviour [54]. Micro-fabric studies in this investigation were carried out using a Philips PSEM-500 scanning electron microscope (SEM) and the procedures followed for the preparation of specimens were as suggested by Smart \& Tovey [55]. The micro-fabric characterization scheme developed by Collins \& Mc Gown (1983) was adopted for the description of the observed micro-fabric features. More than 15 soil samples that cover expansive soils of the three studied bore holes were subjected to scanning electron microscope (SEM) study. The representative SEM micrographs featuring the expansive soils are shown in Figures (14-21).

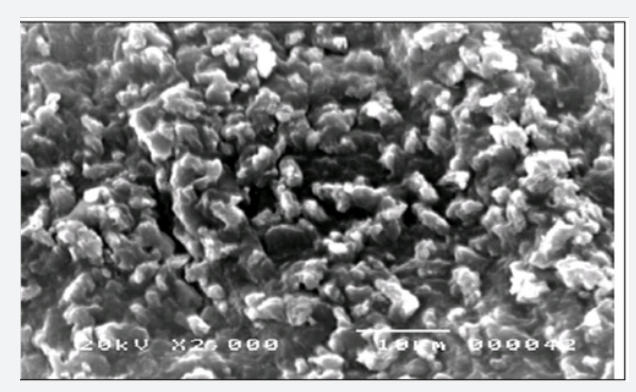

Figure 21: SEM photomicrograph illustrating the flocculation and aggregation fabric of the studied soil (sample I-6).

Initially, the surface of each specimen was scanned at low magnification, which reveals the "general" fabric level (Figure 14,15). At this level, the overall character of the fabric is observed, and representative areas are identified. Micrographs were taken at this low magnification. The magnification was then increased which represents the "intermediate" fabric level (Figure16,17). Further, specimens were examined to assess their pore spaces and the orientation of the soil particles. Finally, the magnification was increased from which represents the "clay particle" fabric level. Micrographs were taken at this level within the representative areas identified earlier. The form of clay particle interaction and the distribution of interparticle pores were carefully examined at this level (Figure 18-19).

The SEM of the studied samples indicated that the fabric of the samples generally consists of dense clay matrices, although clay-granular matrices were observed occasionally (Figure 8-21). In addition, no connectors were observed and only a few aggregations were seen. At the general fabric level (Figure $14,15)$, the sample fabric consists of very uniform matrices with few pore spaces apparent. At the intermediate level, the matrices are composed mainly of dense clay matrices (Figure16,17). The basic pore spaces are mainly of an intra-assemblage type. At the clay particle fabric level as shown surround clay matrices contain a system of clay particles that have a random distribution. Intraassemblage and intra-elemental pore spaces are observed at this level. The appearance of the sample suggests a relatively strong degree of preferred orientation in the phyllosilicates. This is best seen in the relatively low-magnification photographs of sections oriented perpendicular to bedding (Figure 14,20).

The SEM micrographs especially those of parallel sections show dominantly clayey size grained fabrics in which coarser grains (sand-sized grains are negligible but silt-sized grains were seen). The SEM micrographs of the studied samples 


\section{Civil Engineering Research Journal}

especially those of perpendicular sections show flocculation and aggregation that clearly seen in the directions of cracks which due to de-watering. These cracks are parallel, oblique and perpendicular to bedding planes (Figure 14-20).

Comparison shows that there are relatively more planar faces of the platy minerals visible on the sections oriented parallel to bedding (Figure 8-9). Although there is a significant degree of preferred orientation in the views taken at high magnification, the orientation can be seen to be far from perfect in both perpendicular and parallel sections. Nevertheless, the preferred orientation is sufficiently strong to suggest that it may account for the unusual engineering properties of the normally consolidated clays. From the SEM images especially, which taken at high level of magnification it is clear that the dominant micro-fabrics of the studied sediment are of flocculation and aggregation type (Figure 20,21).

Flocculation and aggregation have major effects on engineering properties. Aggregation increases the viscosity, but not much. Flocculated causes a high yield stress and a high viscosity. Flocculation thus makes the soil very stiff and difficult to work. When particles are flocculated, liquids move relatively easily, and permeability is increased. Dispersion, on the other hand, reduces permeability. Particles tend to plug small pores and impede water flow. Flocculation also increases shear strength and reduces compressibility [53-71].

\section{References}

1. Grim RE (1968) Clay Mineralogy. (2 $2^{\text {nd }}$ edn), McGraw-Hill, New York, USA.

2. Sabtan AA (2005) Geotechnical properties of expansive clay shale in Tabuk, Saudi Arabia. Journal of Asian Earth Sciences 25(5): 747-757.

3. Chen, FH (1975) Foundation on Expansive Soil. Elsevier, USA, pp. 1-464.

4. AL-Homoud AS, Khoury H, AL-Omari YA (1996) Mineralogical and engineering properties of problematic expansive clayey beds causing landslides. Bulletin of the International Association of Engineering Geology 54 (1): 13-31. P

5. Abu Seif ES, El-Shater AA (2010) Engineering aspects and associated problems of flood plain deposits in Sohag Governorate, Upper Egypt. Journal of American Science 6(12): 1614-1623.

6. Abduljauwad SN, Hammed RA, Al-Sulaimani GJ, Basunbul IA, Safar MM (1992) Expansive soils in Eastern province of Saudi Arabia. In: Proceedings of the Seventh International Conference on Expansive Soils, Dallas, TX, USA, 3-5 August, Texas Tech University, Dallas, TX, USA, pp. 426-431.

7. Li SL, Qin SJ, Bo ZZ, Shi B (1992) Studies on the Engineering Geology of Expansive Soils in China. Jiangsu Science and Technology Publishing House, Nanjing, China, pp. 212.

8. Al-Rawas, Amer A (1999) The factors controlling the expansive nature of the soils and rocks of northern Oman. Engineering Geology 53: 327 350 .

9. Popescu ME (1986) A comparison between the behaviour of swelling and of collapsing soils. Engineering Geology 23: 145-163.

10. Slater D (1983) Potential expansive soils in Arabian Peninsula. J Am Soc Civil Eng 109 (5): 744-746.
11. Youssef MS, Sabry AA, Tewfik MM (1959) Substantial consolidation and swelling of clay cause two interseting cases of series damage to hospital bulidings in Egypt. Proc of the $4^{\text {th }}$ Inter Conf on Soil Mech and Found. Eng London, UK, p. 462.

12. Edmonstone ZR (1822) A journey to two of the oasis of Upper Egypt. London, pp. 1-152.

13.Zittle AK (1883) Beitraege zur Geologie und Palaontologie der Libyschen Wueste und der angrenzenden Gehiete von Aegypten. Paleontographica 30 (1): 1-237.

14. Hermina MH (1990) The surroundings of Kharga, Dakhla and Farafra oases. In: Said R (Ed.), The geology of Egypt. Balkema, Rotterdam, Netherlands, pp. 259-292.

15. Said R (1962) The geology of Egypt. Elsevier Publishing Company, Amsterdam, Netherland, p. 377.

16. Abbas HL, Habib MM (1971) Stratigraphy of west Mawhoob area, south Western Desert, Egypt. Bulletin Institute Desert Egypt 19 (2): 47-105.

17. Issawi B (1972) Review of Upper Cretaceous-Lower Tertiary stratigraphy in central and southern Egypt. Bulletin American Association Petroleum Geologists 56: 1448-1463.

18. Mansour HH (1973) Geological and sedimentological studies on the Dakhla Oasis area, Western Desert, Egypt. Geology Department, Assuit University, Egypt.

19. Omara S, Philobbos ER, Mansour HH (1976) Contributions to the geology of Dakhla Oasis area, Western Desert, Egypt. Bulletin Faculty of Science, Assuit University, Asyut, Egypt, pp. 319-339.

20. Omara S, Philobbos ER, Mansour HH (1977) Contributions to the geology of Dakhla Oasis area, Western Desert, Egypt: $1^{\text {st }}$ Conf. of Mining and Metallurgical Technology. Assuit University, Asyut, Egypt, p. 21-35.

21. El-Dawoody AS, Zidan MA (1976) Micro and nanopaleoontology of the Upper Cretaceous-Palaaocene succession in west Mawhoob area, Dakhla Oasis, Egypt. Revista Espanola Micropaléontologie VIII 31 : 01 428.

22. Mansour HH, Youssef MM, Khalifa H, El-Younsy AR (1978) Contributions to the stratigraphy and epeirogenesis of the area north west of Kharga Oasis, Western Desert, Egypt. Bulletin Faculty of Science, Assuit University, Asyut, Egypt, pp.161-186.

23. Mansour HH, Issawi B, Askalany MM (1982) Contributions to the geology of west Dakhla Oasis area, Western Desert, Egypt. Annals Geological Survey Egypt 12: 255-281.

24. Askalany MM (1979) Contributions to the geology of west Dakhla area. Western Desert, Geology Department, Assuit University, Egypt.

25. Barthel K.W, Hermann-Degen, W (1981) Late Cretaceous and Early Tertiary stratigraphy in the great Sand Sea and its SDE margins Farafra and Dakhla Oasis South Desert, Egypt. Mitt Bayer Staats. Paleontol. Hist Geol 21: 141-182.

26. El-Younsy AR (1984) Contributions to the geology of the New Valley area, Western Desert, Egypt. Geology Department, Assuit University, Egypt.

27. Luger P, Schrank E (1987) Mesozoic to Palaeogene transgressions in middle and southern Egypt-Summary of palaeontological evidence. In: Matheis G \& Schandelmeier H (Eds.), Current Research in African Earth Sciences. Balkema, Rotterdam, Netherlands, pp. 199-202.

28. Hermina MH (1990) The surroundings of Kharga, Dakhla and Farafra oases. In: Said R (Ed.), The geology of Egypt. Balkema, Rotterdam, Netherlands, pp. 259-292.

29. El-Ezabi MH, El-Araby A (2000) Depositional cycles: an approach to the sequence stratigraphy of the Dakhla Formation, west DakhlaFarafra stretch, Western Desert, Egypt. Journal of Afraican Earth Science 30(4): 971-996. 


\section{Civil Engineering Research Journal}

30. Tantawi AA, Keller G, Adatte T, Stinnesbeck W, Kassab A, Schulte P (2001) Maastrichtian to Paleocene depositional environment of the Dakhla Formation, Western Desert, Egypt: sedimentology, mineralogy, and integrated micro- and macrofossil biostratigraphies. Cretaceous Research vol. 22: 795-827.

31. Holtz WG, Gibbs HJ (1956) Engineering properties of expansive clays. Transactions of ASCE, 21: 641-663.

32. Vijayvergiya VN, Ghazzaly OI (1973) Prediction of swelling potential for natural clays. $3^{\text {rd }}$ Int. Conf. on Expansive Clay Soils. Haifia, Isreal, 1: 227-236.

33. Basta EZ, Abdel Maksoud M, Abdel Aziz T (1979a) Properties and mineralogical constitution of swelling clays from two correlative sections in the Nile Valley and Kharga Oasis, Egypt. Egypt J Geol 23(12): $27-40$

34. Mousa MM (1989) Stratigraphical and sedimentological studies on some Late Cretaceous-Early Tertiary sections in the Eastern Desert, Nile Valley and Western Desert, Egypt. Geology Department Qena Branch, Assuit University, Egypt.

35. Rhoades JD (1982) Soil pH. In: Methods of Soil Analysis, Part A, Chemical and Microbiologica Properties. Agronomy Monogr.

36. Allen SE (1989) Chemical analysis of ecological materials ( $\left.2^{\text {nd }} e d n\right)$, Blackwell Scientific Publication Oxford, London.

37. Jackson ML (1956) Soil chemical analysis: advanced course.

38. Kassif G, Baker R, Ovadia Y (1973) Swell-pressure relationships at constant suction changes. Proc $3^{\text {th }}$ Int Conf Expansive Soils. Haifa, Israel, pp. 201-208.

39. Uppal L, Palit M (1969) Measurment of swelling of expansive soil. $2^{\text {nd }}$ Int Conf. on expansive clay soils, pp. 250.

40. Brackley IJA (1973) Swell under load. Proc. $6^{\text {th }}$ Reg. Conf. for Africa on soil Mech \& Found Eng Durban, South Africa, p. 65-70.

41. Moafi YM (1978) Study of some engineering properties of swelling soils. Al-Azhar University, Egypt, p. 163.

42. Weaver CE (1958) Geological interpretation of clay minerals in sedimentary rock, Clay Minerl. $5^{\text {th }}$ Nat Conf Nat Res Councel Publ, pp. 159-175.

43. Weaver CE (1967) The signficance of clay minerals in sediments, in fundamental aspects of petrol. Geochemistry, Elsevier Publ. Amstrdam, Netherland, pp. 37-75.

44. Carrol D (1970) Clay minerals: a guide to their X-ray identification. Geol. Soc. Am. Spec. paper No. 126, 75p.

45. Chen PY (1977) Table of key lines in x-ray powder identification patterns of minerals in clays and associated rocks. Occas Ind Geol Surv No 21: 1-67.

46. ASTM Designation D 2488-93 (1995) Annual Book of ASTM standards. West Conshohocken, Montgomery.

47. Mackenzie RC (1966) The Differential Thermal Investigations of Clays. Mineral Soc Clay Group, London, UK, pp. 465.

48. Folk RL (1974) Petrology of Sedimentary Rocks. Univeristy of Texas, USA, p. 182.

49. Gromko GJ (1974) Review of expansive soils. Proc ASCE J SMED 100(9): 667-687.
50. Mouroux P, Margon P, Pinte JC (1989) La constrction economique sur les sols gonflants, Marules et methodes 14, BRGM, France.

51. Atterberg A (1911) Die plastizitat der Tone. Inter Mitt Boden I: 4-37.

52. Zacharias G, Ranganathan (1972) Swelling and swelling characteristics of synthetic clays. Proc Symp Str Deform Behavior Soils 1: 129-135.

53. Mitchell JK (1993) Fundamentals of Soil Behavior. (2 ${ }^{\text {nd }}$ Edn), John Wiley \& Sons, New York, USA.

54. Clark JI, Gillott JE (1985) The role of compsition and fabric of soils in selected geotechnical engineering case histories. Applied Clay Science1: 173-191.

55. Smart P, Tovey NK (1982) Electron Microscopy of Soils and Sediments: Technique. Claredon Press, Oxford, UK, pp. 1-264.

56. American Society for Testing and Materials (1995) Standard Practice for Description and Identifcation of Soils (Visual \pm Manual Procedure).

57. Awad GH, Ghobrial MG (1965) Zonal stratigraphy of the Kharga Oasis Geol Surv, Egypt, p. 34-77.

58. Cassagrande A (1932) The structure of clay and its importance in foundation engineering. J Boston Soc. Civil Engrs 19: 168-209.

59. Cassagrande A (1948) Classifcation and identifcation of soils. Transactions of ASCE 113: 901- 992.

60. Cetin H (2004) Soil-particle and pore orientations during consolidation of cohesive soils. Engineering Geology 3: 1 -11.

61. Chamley H (1989) Clay sedimentology.

62. Chamley H, Debrabant P, Robert C, Mascle G, Rehault, JPet al. (1990) Mineralogical and geochemical investigation on latest Miocene deposits in the Tyrrhenian Sea (ODP Leg 107). Proceedings of the Ocean. Drilling program Scientific Results 107: 153-167.

63. El-Askary MA, El-Mahdy OR (1976) The Nubia Sandstone at Kharga Oasis- A fresh deposits: Geochemical evidence. Chem Geol 17: 1-11

64. Krumbein WC, Pettijohn FJ (1938) Manual of sedimentary petrography. Appleton-Century Co, New York, USA.

65. Li SL, Qin SJ, Bo ZZ, Shi B (1992) Studies on the Engineering Geology of Expansive Soils in China. Jiangsu Science and Technology Publishing House, Nanjing, China, pp. 212.

66. Pusch R (1966a) Quick-clay microstructure. Engineering Geology 1(6): 433-443.

67. Pusch R, Ola Karnland, Hrkmark H (1991) The nature of expanding clays as exemplified by the multifaced smectite mineral montmorillonite. Int. Workshop Stress Partitioning in Engineering Clay Barriers, Duke Univ, North Carolina, USA, p. 1-23.

68. Terzaghi K (1927) Soil classification for foundation purposes. Trans. $1^{\text {st }}$ Int Cong Soil Sci 4: 127- 157.

69. Terzaghi K (1928) The physical properties of clays. MIT Tech Eng News $9(10): 11-36$

70. Terzaghi K (1943) Theoretical soil mechanics. Jhon Wiley and Sons, New York, USA.

71. Tourtelot HA (1973) Geologic origin and distribution of swelling clays. In: Proceedings of the Workshop on Expansive Clays and Shales in Highway Design and Construction, Denver, CO, Federal Highway Administration, Wyoming University, Laramie 1: 44-69. 

(CC) This work is licensed under Creative DOI: 10.19080/CERJ.2019.07.555707

\section{Your next submission with Juniper Publishers} will reach you the below assets

- Quality Editorial service

- Swift Peer Review

- Reprints availability

- E-prints Service

- Manuscript Podcast for convenient understanding

- Global attainment for your research

- Manuscript accessibility in different formats

( Pdf, E-pub, Full Text, Audio)

- Unceasing customer service

Track the below URL for one-step submission https://juniperpublishers.com/online-submission.php 